\title{
THE LIFE OF A FOREIGN TRAVELER IN RUSSIA ACCORDING TO JOHANN ARNOLD BRAND'S DICTIONARY-PHRASEBOOK, 1673
}

\section{Yulia V. Kolpakova ${ }^{1}$ (a), Maksim Y. Kolpakov² (a)}

(a) Pskov State University. Pskov, Russia

\begin{abstract}
The article provides for an overview of foreigners' encounter with the Russian language in the 16th - early 18th centuries; it analyzes, for this purpose, the GermanRussian dictionary-phrasebook from the diary "Journey through Brandenburg, Prussia, Courland, Livonia, Pskov, Veliky Novgorod, Tver and Moscow” by Johann Arnold Brand. The phrasebook "Some Muscovite words and expressions that may be useful to travelers", compiled by Brand on the way from Pskov to Moscow, contains the names of body parts, clothing, household accessories, dishes and drinks, food products, interior items, transport, utensils, writing tools in Russian transliteration with the translation into German. It also includes ready-made speech structures for communicating with fellow travelers, coachmen, owners and staff of the inns, for disposing of servants and property. The analysis of the phrasebook made it possible to recreate the everyday realities of the life of the Brandenburg Embassy on the road, and situations of lexical exchange. The authors provide a commented version of the literal reading of words and expressions in Russian. The independent study of the local language in Russia by foreign travelers was the most effective way to overcome the communication barrier and improve living conditions when traveling to the borderlands. The source under study may be of interest to both historians of the frontier and specialists in material culture and linguistics.
\end{abstract}

\section{Keywords}

dictionary-phrasebook; German-Russian dictionary; road vocabulary; Russian everyday speech of the 17th century; roads; traveler's life; notes of foreigners; Pskov borderland; Brandenburg Embassy; Russian tzardom

This work is licensed under a Creative Commons «Attribution» 4.0 International License

1 Email: pskov-sova[at]mail.ru

2 Email: kolpakov.m[at]gmail.com 


\section{БЫТ ИНОСТРАННОГО ПУТЕШЕСТВЕННИКА В РОССИИ, СОГЛАСНО СЛОВАРЮ- РАЗГОВОРНИКУ ИОГАННА АРНОЛЬДА БРАНДА, 1673 ГОД}

Колпакова Юлия Вячеславовна ${ }^{1}$ (a), Колпаков Максим Юрьевич ${ }^{2}$ (a)

(а) Псковский государственный университет. Псков, Россия

\section{Аннотация}

В статье дается обзор опыта знакомства иностранцев XVI - начала XVIII вв. с русским языком; с этой целью анализируется немецко-русский словарьразговорник из дневника «Путешествие через Бранденбург, Пруссию, Курляндию, Лифляндию, Псков, Великий Новгород, Тверь и Москву» Иоганна Арнольда Бранда. Разговорник «Некоторые московитские слова и выражения, которые могут пригодиться путешественникам», составленный в дороге от Пскова до Москвы, содержит названия частей тела, одежды, бытовых аксессуаров, блюд и напитков, продуктов, предметов интерьера, транспорта, утвари, принадлежностей для письма на русском языке в транслитерации с переводом на немецкий. Он также включает готовые конструкции для общения с попутчиками, ямщиками, хозяевами и персоналом постоялых дворов, для распоряжения слугами и имуществом. Анализ словаря-разговорника позволил воссоздать бытовые реалии жизни Бранденбургского посольства в дороге, ситуации обмена лексикой. Авторы приводят комментированную версию буквального прочтения слов и выражений на русском языке. Самостоятельное изучение в России иностранными путешественниками местного языка было наиболее действенным способом преодоления коммуникативного барьера и улучшения бытовых условий при путешествии в пограничье. Исследуемый источник может быть интересен как историкам фронтира, так и специалистам по материальной культуре, и лингвистам.

\section{Ключевые слова}

словарь-разговорник; немецко-русский словарь; дорожная лексика; русская обиходная речь XVII в.; дороги; быт путешественника; записки иностранцев; псковское пограничье; бранденбургское посольство; Российское царство

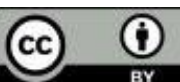

Это произведение доступно по лицензии Creative Commons «Attribution» («Атрибуция») 4.0 Всемирная

1 Email: pskov-sova[at]mail.ru

2 Email: kolpakov.m[at]gmail.com 


\section{ВВЕДЕНИЕ}

В период раннего Нового времени частные деловые и официальные поездки по дорогам русского пограничья, длительные путешествия в столицу Московского царства подразумевали активные социальные контакты иностранных путешественников с проводниками, возчиками, персоналом постоялых дворов, чиновниками, жителями придорожных населенных пунктов. Свободному общению европейцев и русских препятствовали не только ограничения со стороны органов власти, но и языковой барьер. Поиск способов межкультурной коммуникации в общих торговых, политических, культурных и гуманитарных интересах, которым были заняты иностранные путешественники, остается актуальной проблемой и по сей день.

B XVI-XVII вв. Псковская земля являлась транзитным регионом для частных лиц, торговых миссий и дипломатических делегаций, совершавших поездки из Ливонии и Польши (или через Ливонию и Польшу) в Московское царство. Население псковско-литовского приграничья было славяноязычным. Распространенные в Ливонии языки с лингвистической точки зрения не являлись родственными по отношению к русскому. Латинский язык на территории России не мог выступать в роли языка-посредника при торговых и дипломатических контактах. Знание русского языка среди жителей Ливонии было ситуативным и довольно ограниченным. Его, как свидетельствуют источники, сознательно изучали торговцы, поскольку язык становился преимуществом, открывающим доступ к рынкам (Селарт, 2014).

Европейские послы традиционно испытывали недоверие к переводчикам, предоставленным русскими властями. В штат иностранных миссий в Россию обязательно включали одного или несколько человек, владевших русским языком. Дипломат Антонио Поссевино, обобщивший чужой и личный опыт, идеальными кандидатурами на должность переводчика называл нанятых в Польше людей пожилого возраста, «менее склонных к обману», в хорошем варианте владеющих языками священников или врачей (Поссевино, 1983, cc. 68-71).

В частных поездках по России европейцы, не владевшие русским языком, все же обращались к услугам переводчиков. Ими могли быть такие же иностранцы - компаньоны, случайные попутчики. Так, Самуэль Кихель прибыл в 1585 г. из Дерпта в Псков с рижским купцом, через которого и общался с русскими (Кирпичников, 1994, с. 4). Немцу Иоганну Вундереру во время прогулки по Пскову в 1590 г. помогал «литовский покровитель» (1995, с. 219). 
Известны примеры, когда путешественникам приходили на помощь местные жители, немного владевшие немецким языком, а также проживавшие в Русском государстве европейцы. По свидетельству Ганса Морица Айрманна, немца из свиты шведского посланника графа Христиана Горна, многие торговцы в Москве зимой 1669-1670 гг. говорили «по-шведски, польски, фински, немногие - по-нижнегермански» (Левинсон, 1945, с. 279). Но для полноценного общения Айрманну приходилось комбинировать элементы разговора на всех перечисленных языках.

Знание иностранных языков не было широко распространено и в провинциальной русской среде. В 1726 г. по недавнему руссколивонскому пограничью путешествовал дворянин Обри де Ла Моттре. Помимо французского, он владел английским, немецким, латинским и греческим языками. Оказавшись в Дерпте, Ла Моттре дорожил обществом двух попутчиков-торговцев: один из них в достаточной степени знал латынь, а второй немного владел немецким (La Mottraye, 1732, pp. 203-204). В Пскове француз познакомился с собиравшейся ехать в Великий Новгород группой из четырех купцов и одного русского священника, которым его отрекомендовали два спутника по предыдущей части путешествия. Выяснилось, что только один из потенциальных попутчиков очень поверхностно знал немецкий язык, а остальные понимали только «славянский». Поэтому во время поездки до Новгорода Ла Моттре общался в группе с помощью записок на «славянском» и немного говорил по-немецки (La Mottraye, 1732, p. 206).

Самым действенным способом преодолеть трудности общения было изучение русского языка. В феврале 1665 г., во время пребывания в Москве, голландский дипломат Николаас Витсен, нанял себе учителя русского языка. Правда, образовательный процесс был сорван, так как думный дьяк Алмаз Иванов запретил приводить учителя в резиденцию посольства (Витсен, 1996, с. 117). Путешественник, парусный мастер Ян Стрейс в 1668 г. стал изучать «язык московитов», общаясь с возницами. Голландец легко усваивал язык и «за короткое время знал его настолько, что мог объясняться» (Стрейс, 1935, с. 148).

B XVI-XVII вв. европейцами были созданы пособия для изучения обиходного русского языка. Авторы разговорников использовали латинский алфавит для транскрипции русских слов. Содержание пособий зависело от потребностей их составителей. В настоящее время в научный оборот введено шестнадцать таких словарей-разговорников (Левичкин, 2017, с. 196-198). Фонетика, грамматика, лексика и фразеология в трех пособиях (анонимный русско-немецкий разговорник XVI 
в., словарь Томаса Шрове и словарь Тонни Фенне), предназначенных для ганзейских купцов, позволила исследователям соотнести русскую составляющую языка этих разговорников с псковским диалектом (Болек, 2003; Хорошкевич, 1999). Тексты указанных сочинений неоднократно привлекались в качестве источника сведений по истории торговли и быта псковичей в ранее Новое время (Костючук, 2003, 2020; Мжельская, 1984, 1988, 2003, 2010; Мжельская \& Костючук, 2003).

В этот же ранненововременной период создаются пособия и для изучения других славянских языков. Так, в 1539 г. в Кракове был впервые напечатан "Książeczek polskich", который позднее неоднократно переиздавался в течение второй половины XVI в. В состав этого польско-немецкого разговорника, кроме повседневных фраз, были включены тексты молитв на польском языке, немецкие и польские образцы писем (Болек, 2003, с. 215).

\section{ИСТОРИЯ СОЗДАНИЯ И ИЗУЧЕНИЯ СЛОВАРЯ- РАЗГОВОРНИКА «НЕКОТОРЫЕ МОСКОВИТСКИЕ СЛОВА И ВЫРАЖЕНИЯ, КОТОРЫЕ МОГУТ ПРИГОДИТЬСЯ ПУТЕШЕСТВЕННИКАМ»}

В самом начале польско-турецкой войны 1672-1676 гг. царь Алексей Михайлович отправил к бранденбургскому курфюрсту предложение о создании антитурецкой коалиции (Hirsch, 1906, s. 269). В это время Фридрих Вильгельм уже принимал деятельное участие в организованной Голландией в 1672 г. антифранцузской коалиции. Великий курффюрст отказался от предложения русского царя, поскольку бранденбургской армии было необходимо остановить французское вторжение в Вестфалию (Hirsch, 1906, s. 270). В 1673 г. Фридрих Вильгельм заключил сепаратный мир с Францией и стал искать союза с Русским государством. В августе 1673 г. дипломатическая миссия отправилась в Москву (Hirsch, 1906, ss. 270-273). В свиту посла Иоахима Скультета и был включен юрист Иоганн Арнольд Бранд.

Биографические сведения о Бранде очень скудны. Известно, что он родился 27 июля 1647 г. в нидерландском городе Девентер (провинция Оверэйссел). Бранд обучался в нескольких университетах. В 1680 г. он стал доктором права и служил адвокатом в городском суде Клеве. С 1683 г. и до своей смерти (25 июня 1691 г.) Иоганн Арнольд Бранд занимал должность профессора права в Дуйсбургском университете (Günther, 1965, s. 757).

Во время путешествия в Москву Бранд вел путевой дневник и собирал сведения о Курляндии, Лифояндии и Московии. Эти рукописные материалы были переданы его родственниками Иоганну фон 
Хеннину, профессору Дюйсбургского университета, который издал их в 1702 году (Brand, 1702). На русском языке опубликовано два кратких фрагмента из «Путешествия через Бранденбург, Пруссию, Курляндию, Лифляндию, Псков, Великий Новгород, Тверь и Москву»: описание пребывания посольства в Великом Новгороде (Коваленко, 2002) и пересказ свидетельства Альбрехта Доббина о ловле соболей в Сибири (Алексеев, 1936).

Согласно дневнику Иоганна Арнольда Бранда, бранденбургское посольство задержалось на пять недель в Кенигсберге. После завершения сбора всех подарков для русского царя, 7 октября делегация продолжила поездку в сторону Москвы (Brand, 1702, ss. 23, 47) и 2 ноября прибыла в пограничный замок Нейгаузен (Brand, 1702, ss. 126-127). Посольство пересекло границу 7 ноября (Brand, 1702, s. 173), быстро продвигалось на Москву по дороге через Псков, Великий Новгород и Тверь. Дипломатическая миссия прибыла в столицу 4 декабря. На следующий день состоялась встреча Иоахима Скультета с Алексеем Михайловичем, в ходе которой были обсуждены вопросы турецкой угрозы, взаимоотношения сторон с Речью Посполитой и Швецией, судьба городов Себежа и Невеля (Бантыш-Каменский, 1902, сc. 12-14; Форстен, 1900, сc. 53-58; Hirsch, 1906, pp. 276-279). В обратный путь посольство отправилось 14 декабря и уже 26 декабря покинуло территорию России (Brand, 1702, ss. 245, 251).

Частью дневника Иоганна Арнольда Бранда является словарьразговорник под названием «Некоторые московитские слова и выражения, которые могут пригодиться путешественникам». В опубликованном Иоганном фон Хеннином словаре-разговорнике И.-А. Бранда есть также колонтитул "Moscovische Anmerckungen" (условно, «Московские заметки»).

В издании 1702 г. учебное руководство занимает 9 страниц: с 258 по 266, текст разделен иллюстративной вставкой - таблицей со славянским алфавитом, взятой из сочинения Адама Олеария. Кроме этого, И.-А. Бранд уделяет внимание истории русских азбук в другой части своего дневника (Brand, 1702, ss. 428-430). Это не первая его любительская языковая штудия - в более ранней части дневника, касающейся Риги, он помещает разговорник для общения на «ливонском» (Lithaumer, Lieffland), запись песни и псалмов на «ливонском» из сочинения Mr. Daniels Klein, 1666 г. (Brand, 1702, cc. 102-116).

В 1965 г. Э. Гюнтер опубликовала текст разговорника на немецком языке и проанализировала транскрипцию записей русских слов и оборотов речи (Günther, 1965). Э. Гюнтер не рассматривала словарь как 
источник по истории дорожной повседневности и по взаимоотношениям иностранцев с русскими. В советской и российской историографии словарь-разговорник никогда не изучался. Краткое перечисление содержания словаря Бранда приведено в работе Л. Н. Пушкарева (Пушкарев, 2004, с. 125). Настоящая публикация имеет целью обзор и частичный перевод источника, рассмотрение его в контексте аналогичных сочинений с точки зрения реалий материальной культуры. Авторы статьи пользуются главным образом методами логико-семантического и компаративистского анализа.

\section{СОСТАВ И СОДЕРЖАНИЕ СЛОВАРЯ-РАЗГОВОРНИКА}

В словаре-разговорнике его автор разделил слова и выражения на тематические группы, такие, как принадлежащие к числам и счету, к частям тела, предметам одежды, к дорожному лексикону. Однако внутри групп систематизация слов отсутствует или условна нет ни алфавитного, ни тематического порядка. Не будучи лингвистом, И.-А. Бранд был любознательным путешественником, проявлявшим живой интерес ко всему иноземному, но не имевшим квалификации, чтобы свести полученные сведения в научно обоснованную систему. Вероятно, выяснение значений происходило в процессе натурного показа предметов. Видно, например, что показ частей тела шёл преимущественно сверху вниз по фигуре, показ одежды и принадлежностей костюма - от пояса, хотя и с некоторыми объяснимыми отступлениями и возвратами. При переносе слов из черновых заметок в итоговый текст автор и издатель не стали совершенствовать изначальный порядок.

Большая часть транслитерированных И.-А. Брандом слов интуитивно понятны русскому читателю и без немецкого перевода. Поэтому перевод немецкого перевода И.-А. Бранда обратно на русский язык представляется нам в тексте данной статьи избыточным. Будем отмечать лишь те случаи, когда перевод автора явно расходится с приведенным русским словом или выражением, либо может прояснить спорные места. Представляется важным уделить больше внимания русским словам в передаче И.-А. Бранда, и приводимое нами «буквальное прочтение» - это предположение относительно того, как могли звучать русские слова и фразы в исполнении автора словаря-разговорника, а «перевод» в квадратных скобках - это разъяснение написанных латиницей русских слов ${ }^{1}$. Расшифровка словаря

1 Благодарим доктора филологических наук, профессора кафедры филологии, коммуникаций и русского языка как иностранного Псковского государственного университета Ларису Яковлевну Костючук за консультацию и советы по представлению текста И.-А. Бранда. 
на немецком языке доступна читателю в публикации Э. Гюнтер (Günther, 1965).

Свой словарь Иоганн Арнольд Бранд начинает с лексики, необходимой для счета на русском языке. В раздел «Числа» он помещает такие слова, как «perrowoy» - букв., перровой [первый], «drugoy» другой, или второй, «tri» - три, «tschattíri» - букв., чаттыри [четыре], «piad»- букв., пядь [пять], «ssiest»- букв., ссесть [шесть], «sschjéme»букв., сшьеме [семь], «wosmi»- букв., восми [восемь], «dewet»- букв., девет [девять], «dezet» - букв., децет [десять], «odínatzet» - букв., одинатцет [одиннадцать], «dwenatzet»- букв., двенатцет [двенадцать], «trinatzet» - букв., тринатцет [тринадцать], «tschattirinatzet» - букв., чаттиринатцет [четырнадцать], «piadnatzet»- букв., пяднатцет [пятнадцать], а также «dwatzet» - букв., дватцет [двадцать], «perrowoydwatzet» - букв., перровойдватцет [двадцать первый или двадцать один], «tritzet» - букв., тритцет [тридцать], «perroxvoy-tritzet» - букв., перроксвой-тритцет [тридцать первый или тридцать один], «ssorock» - букв., ссорок [сорок], «piad-dezat» - букв., пядь-децат [пятьдесят]. После чисел «пятнадцать», «двадцать один» и «пятьдесят» И.-А. Бранд позволяет читателю самому конструировать числительные, трижды добавляя: «и так далее» (дословно, «und so ferner»). В рассказе о русских азбуках он поясняет, что русские числа для своего сочинения позаимствовал из текста Адама Олеария (Brand, 1702, s. 430).

Под заголовком «Члены (конечности) тела» (Glieder des Leibs) в словаре расположены: «glasa» - глаза, «barada» - букв., барада [борода], «ouss»- yc, «nôs» - ноc, «rôt» - poт, «jasyk»- букв., язик [язык], «sube» - букв., зубе [зубы], «guba» - губа, «ssôke» - букв., ссёке [щёки], «brôvi» - букв., брёви [брови], «ouschje» - уши, «pleetzo» букв., плетцо [плечо], «lokaetz» - букв., локатц [локоть], «paeltz» - букв., пелтц [палец], «ruka» - рука, «nokat» - букв., нокат [ноготь], «ssustaetz» - букв., ссустаетц [суставец], «gorrla» - букв., горрла [горло], «sschéja» букв., сшея, шея (?) [шея], «spina» - спина, «boolssjey» - букв., боолсшей [большой палец], «loop» - букв., лооп [лоб], «missynjetz» - букв., миссинетц [мизинец], «reôbra» - рёбра, «wollosse»- букв., волоссе [волосы], «роup» - пуп, «breougcha» - букв., брюгха [брюхо], «gssuj» - букв., гссуй, «naga» - букв., нага [нога], «kalyna» - букв., калина [колено], «peta» - букв., пета [пята], «ykra» - икра, «golin»- букв., голин [голень], «руsta» - букв., писта, что автор деликатно переводит латинским «membrum muliebre», «beaudra» - бёдра, «gousna»- букв., гузна [гузно]. К первому значению при переводе слова «beaudra»- «бедро, бёдра» автор добавил второе - «ягодицы». 
Для перевода термина «gssuj», сообщенного автору вместо книжного «уд», И.-А. Бранд использует немецкое «стыд» (scham). Слово «ус» у автора, вероятно, ошибочно, переводится как «knebel» (колено). Слову «djytska» [дядька - ?] в данном разделе соответствует перевод «грудь», и это вряд ли отражает какое-то местное наименование части тела. Вероятнее всего, ошибка возникла из-за характерного жеста указания на себя/указания на грудь. В данном случае респондент представился, хотя и не назвал имени. В целом, содержание и компоновка названных слов также скорее указывает на то, что информант Иоганна Бранда был мужчиной.

Тема описания внешности продолжается в разделе «Вещи, относящиеся к одежде и уходу за телом» (Zur Kleydung und dienst des Leib gehörige dinge). Здесь И.-А. Бранд помещает такие слова, как «preâska»букв., пряшка [пряжка], «spaga» - шпага, «јupa» - букв., юпа [юбка], «kaftaen» - кафтан, «puguvytze» - букв., пугувитце [пуговицы], «basmaek» - башмак, «tzulok» - букв., тцулок [чулок], «sstane» - букв., сстане или штане [штаны], «rokávytze» - букв., рокавитце [рукавицы], «peristrancky» - букв., перистранки [И.-А. Бранд поясняет, что это вязаные перчатки], «ssleapa» - букв., сслапа или шлапа [шляпа], «rubáecha» - pyбaxa, «reemen» - букв., ремен [ремень], «wytkail» букв., виткайл, «sskuffia» - скуфия, «künitza» - букв., кюнитца [куница], «plaet» - плат, «kaermahn» - карман.

Автор разговорника полагает, скуфья - это ночной колпак, ночная шапочка, но не головной убор монаха или священнослужителя, а также поясняет, что плат - это носовой платок, а карман - мешочек или «schiebsack».

Слово «wytkail» появляется в словаре, когда автор пытается выяснить русское название слова «halßtuh» (галстук, шейный платок), и вряд ли соответствует значению.

В раздел «Пища и напитки, и всё, что к ним относится» (Sрсуґ иnd Tranck/und was dazu schönt) автор помещает названия продуктов, приправ и напитков: «mugcha» - букв., мугха [мука], «jáitze» - букв., яйтце [яйца], «karaffé» - букв., караффе́ [каравай], «sseaul» - соль, «massla» - букв., массла [масло], «poёretz» - букв., пёретц [перец], «ryba» - букв., риба [рыба], «barana» - букв., барана [баран], «gous» букв., гус [гусь], «kuritza» - букв., куритца [курица], «indeiska kuriska» букв., индейска куриска [индейка], «уssum»- изюм, «gorilka wina»букв., горилка вина [вино/бренди], «ріwа» - букв., пива [пиво].

Здесь же перечислены необходимые для приготовления и употребления пищи или напитков предметы: «drova» - дрова, «oogoín» - букв., оогоин [огонь], «uguel» - уголь, «ssreblitz»- букв., 
среблитц [скребница (?)], «upollowna» - букв., уполовна [половник], «upollowna rieetka» - букв., уполовна риетка, «ssklanitza» - букв., сскланитца или шкланитца [скляница], «stool» - стол, «neauzjyck» - ножик, «wiltz»- букв., вильтц [вильца, вилка], «tzeeren» - букв., тцерен [черен = ручка ножа], «neausny» - ножны либо «ножни», ножницы.

Также в перечень входит «potz sswysnick» - подсвечник, но в переводе у автора указана rothe Rübe (красная свекла), что может указывать на недоразумение. Названия половников автор переводит как Kochlöffel (кухонная ложка) и Shaumlöffel (ложка для снятия пены).

Далее словарь прямо внутри раздела переходит в формат разговорника, и в тексте появляются готовые конструкции, в том числе, с новыми словами (молоко, вода, жаркое «schjalyck», капуста, курица, хлеб).

\section{У автора}

Prynessi na dwá copyke sswyzja molokka

Dóoytte matska molokka?

Davai póvar woda

Peauverty schjalyck

Jessle utebéa Sswezja capusta?

Jessle utebéa dobbra, choroschja, piwa?

Pookroy sstool

Wostmy protsch

Daimene ssweeschja chólotna woda

Khiópla woda

Jatwoi sdorovia piú
Буквальное прочтение, перевод, пояснения

букв., Принесси на два копийке свижа молокка [Принеси на две копейки свежего молока]

букв., Дойтте матска молокка [Дайте, матушка, молока]

букв., Давай повар вода [Дай, повар, воды]

букв., Поверти шялык [шашлык] [Автор переводит это как wend den Braten«переверни жаркое»]

букв., Ессле у тебеа ссвежья капуста? [Есть ли у тебя свежая капуста?]

букв., Ессле у тебя доббра хорошья пива? [Есть ли у тебя доброе хорошее пиво?]

букв., Поокрой сстол [Накрой на стол (?)]

букв., Возтми протч [Возьми, т.е. забери, унеси прочь - народное]. Согласно пояснению автора, это должно означать «унеси это блюдо», nehm den Disch auf

букв., Дай мене свежья холотна вода [Дай мне свежую холодную воду]

букв., Хиопла вода [Тёплая вода]

Возможно, в тексте описка или опечатка, $u$ на месте «Кh» должна быть «Тh»

букв., Я твой здоровия пью [Я пью за твое 
здоровье]

Budis doróve

Sspassibo

To poslanick sdorovia букв., Будис дорове [Будь здоров]

Спасибо

букв., То посланик здоровия [Здоровья посланнику (?)]

Автор переводит это как Ich bring dir des $H$. Ubgesandten Gesundheit

Je tibi wina dam

букв., Я тиби вина дам [Я тебе вина дам]

Daimene, kaktebe yswohlit, ot kuritza

букв., Дай мене как тебе изволит, от куритца

[Дай мне, какую изволишь, часть курицы]

букв., Риж моне хлеба [<От>режь мне хлеба]

букв., Эвод возми хлеба [Вот, возьми хлеба]

\section{Таблица 1. | Table 1.}

Фразы из раздела о трапезе позволяют воссоздать живые диалоги в корчме между иностранцами и местными хозяевами. Заметно, что гость одновременно пытается быть и требовательным, и вежливым посетителем, либо его подвигают к тому снабжающие его лексикой информанты (ср. «Davai póvar woda», «Pookroy sstool», с одной стороны, и «Daimene, kaktebe yswohlit», «Daime laesku natzem ssedsjítz»). Возглас «То poslanick sdorovia» наводит на мысль о коллективных трапезах посольской делегации в гостях у русских должностных лиц, где из уст хозяев мог прозвучать подобный тост.

Отличительной чертой словаря-разговорника Иоганна Бранда является наличие обширного раздела о письменных принадлежностях. Эти предметы, вероятно, автор пытался добыть в каком-либо месте, где посольство останавливалось на подворье. По повторам и несостыковкам в разделе можно осторожно предположить, что И.-А. Бранд испытал довольно большие затруднения с получением необходимых вещей.

В данный раздел - «Принадлежности для письма и прочее» (SchreibGeräth / und ander mehr) помещены такие слова, как «koryga» - букв., корига [автор переводит это как Schreib buch]; «bulaefka» - букв., булафка [при этом автор переводит слово как Schreib stuhl - «стул для письма»]; «sserlynitza» - букв., серлинитца [чернильница]; «bumágua» - бумага; «pieaureau» - перо; «ssteaul» - букв., стол [но автор переводит слово как dinte - «чернила»]; «kosja» - букв., косья [кожа или козья, в переводе автора - uinschlag eines buchs, «обложка книги»]; «pissoók» букв., писок [песок для присыпания написанного чернилами]; 
«peausswiroelka»-[вероятно, песочница, письменный прибор, либо пресс, у И.-А. Бранда - pseisse]; «ssypietz» - букв., ссыпец [сыпец = сосуд для песка из письменного прибора, но у автора - licht putz]; «teaupoór» - букв., топор [автор переводит как becken]; «sstulea» - букв., сстулеа или сстуло [автор переводит словом block]; «zirkola» - букв., зиркола [зеркало]; «griebin» - букв., гребин [гребень, но автор переводит как kamin]; «kudri» - кудри; «opoijaska» - опояска, но автором переведено, как velour - «велюр», «бархат»; «sswieetsche» - букв., свече [свеча]; «to ridwaen» - букв., то ридван [повозка, рыдван]; «karéta» - карета; «koleósza» - букв., колеосца [колеса].

Из всего сочинения именно данный блок лексики обладает наименьшей прозрачностью для перевода. Возможно, часть слов и значений была перепутана или искажена при печати дневника. Не исключено, что оригинальные записки в этой части могли быть обрывочны или дефектны, что информанты были неверно поняты. Во всяком случае, сочетание слова «булавка» с переводом «стул для письма» (возможно, стило для письма?), слова «ssteul» (стол?) с переводом «чернила», слова «teaupoór» (топор?) с переводом «becken» (в значении «сосуд»?) в первом приближении вызывает недоумение. Нет ясности и с переводом первого слова в разделе - «koryga». Выскажем предположение, что в рукописи Иоганна Бранда вместо этого слова могла быть просто «knyga». Перевод «kamin» для «griebin», может быть, не является ошибкой, а восходит к «сатіпо» («гребешок»).

Помещение в данную часть лексики, связанной с уходом за собой и гигиеной (гребень, зеркало), может иметь только ситуативное объяснение, связанное с путевыми потребностями или наличием в соответствующем месте описанных в разделе предметов.

В раздел попадает и дорожная лексика: карета, рыдван, колеса видимо, из-за связи с почтовой службой и ямскими реалиями. Это позволяет предположить, что поиск письменных принадлежностей Иоганн Бранд пытался осуществить на постое в почтовом яме.

Бросается в глаза, что передача звуков в словах данного раздела отличается избыточностью, переусложненностью (напр. «Sswieetsche», «Pieaureau»). И.-А. Бранд не декларировал в своем словаре-разговорнике никаких правил передачи звуков немецкими буквами, и в сочинении нет единой системы. Он пытался выработать наиболее удачную транскрипцию по ходу составления словаря-разговорника, мог пользоваться советами каких-либо людей, но и респонденты автора по разным разделам могли иметь свои особенности произношения.

Наиболее объемная часть словарного сочинения Иоганна Бранда раздел «Всякие вещи в путешествиях» (Allerhand in reisen dientich). 
Раздел начинается со слов «Dwornik, Dwornitza» (хозяин/управляющий гостиницей и хозяйка гостиницы), но вся оставшаяся его часть выстроена, как разговорник.

Часть выражений относится к универсальным случаям общения, часть призвана помочь в общении с прислугой, особенно в ситуациях с поклажей.

\begin{tabular}{|c|c|}
\hline У автора: & Буквальное прочтение, перевод, пояснения: \\
\hline Ssluschaytis? & букв., Сслушаитис? [Слушайтесь] \\
\hline Ssluchay & $\begin{array}{l}\text { букв., Слухай } \\
\text { И.-А. Бранд переводит это, как «Нӧrе du» (mы } \\
\text { слушай?). }\end{array}$ \\
\hline Stó gchótsschjes? & букв., Сто гхоцчис? [Что хочешь?] \\
\hline Klikay tot schjollovjick & $\begin{array}{l}\text { букв., Кликай тот чолловик [Кликни, m.е. позови } \\
\text { или окликни того человека] }\end{array}$ \\
\hline Ny gray drougues & $\begin{array}{l}\text { букв., Ни грай ...дрогас (?) } \\
\text { Неясное место, авторский перевод: «Macht kein } \\
\text { geschrey» (не кричи). «Грай» может означить крик, } \\
\text { шум. }\end{array}$ \\
\hline Kien naeszin & букв., Кин назин [Кинь наземь (?), т.е. сбрось] \\
\hline Dobbróste & $\begin{array}{l}\text { букв., Добросьте [Да брось ты или Да бросьте] } \\
\text { Перевод И.-А. Бранда гласит «еs ist gut» }\end{array}$ \\
\hline Ach de ti stóis? & букв., Ах де ти штоис [Ах, где ты стоишь?] \\
\hline Wót sterrá & букв., Вот стерра [Вот здесь, шутл.?] \\
\hline Wienezí koropki wohn & букв., Винеци коропки вон [Вынеси коробки вон] \\
\hline Prienczí nate éga koropka & $\begin{array}{l}\text { букв., Принези на те<л>ега коропка [Принеси, m.e. } \\
\text { перенеси, на телегу коробку] }\end{array}$ \\
\hline Wosmi nazim schjemodan & $\begin{array}{l}\text { букв., Возми нацим чемодан [Возьми наш } \\
\text { (наземь?) чемодан] }\end{array}$ \\
\hline $\begin{array}{l}\text { Stoï taem gdié phzanie } \\
\text { stoid }\end{array}$ & $\begin{array}{l}\text { букв., Стой там где фсани стоид [Стой там, где } \\
\text { сани стоят] }\end{array}$ \\
\hline $\begin{array}{l}\text { Stoi taem gdié loosjed } \\
\text { stoïd }\end{array}$ & $\begin{array}{l}\text { букв., Стой там где лоошедь стоид [Стой там, где } \\
\text { лошадь стоит] }\end{array}$ \\
\hline
\end{tabular}

Таблица 2. | Table 2.

Небольшой блок общих фраз предназначен, возможно, для облегчения общения с попутчиками, с другими постояльцами, с хозяевами, ямщиками: 


\begin{tabular}{ll}
\hline У автора: & Буквальное прочтение, перевод, пояснения: \\
\hline Zdorove zjiveósteri? & $\begin{array}{l}\text { букв., Здорове живёстери [Здорово живёшь, } \\
\text { шутл.?] }\end{array}$ \\
Sdoróvoy zjiveósch? & букв., Здоровой живёш [Здорово живёшь?] \\
Ja twoi Sslugasteri & букв., Я твой слугастери [Я твой слуга? шутл.?] \\
Prostyste & букв., Простисте [Простите] \\
Pudy spaetz & букв., Пуди спатц [Поди спать] \\
Da jútero ránno stavay & букв., Да утеро ранно ставай [Утром рано вставай] \\
Prósty drugne & букв., Прости другне \\
& И.-А. Бранд переводит это: «Хорошо, мой друг» \\
Dobro utero & букв., Добро утеро [Доброе утро] \\
Dobro weetsjor & букв., Добро вечор [Добрый вечер] \\
\hline
\end{tabular}

Таблица 3. | Table 3.

Часть фраз непосредственно относится к общению с ямщиками, а также к верховой езде:

\begin{tabular}{|c|c|}
\hline У автора: & Буквальное прочтение, перевод, пояснения: \\
\hline Phtottssjai gotof & букв., Фтотчай готоф [Тотчас готов] \\
\hline $\begin{array}{l}\text { Jem ssjick miessjock } \\
\text { semno }\end{array}$ & букв., Йем щик мешок семно [Ямщик, мешок сена] \\
\hline $\begin{array}{l}\text { Wykin wohn ssolóma } \\
\text { miessjock? }\end{array}$ & $\begin{array}{l}\text { букв., Викин вон солома мешок [Выкинь вон } \\
\text { мешок соломы]. }\end{array}$ \\
\hline León & Лён \\
\hline $\begin{array}{l}\text { Pregay phsanie, losschjet } \\
\text { jam ssjik }\end{array}$ & $\begin{array}{l}\text { букв., Прегай фсани лошадь йам щик [Запрягай } \\
\text { в сани лошадь, ямщик] }\end{array}$ \\
\hline Poye schjay & букв., Пое шай [Поезжай, поехай] \\
\hline Ponnessi ssoloma wohn & $\begin{array}{l}\text { букв., Поннесси ссолома вон [Понеси, т.е. вынеси } \\
\text { или отнеси солому вон] }\end{array}$ \\
\hline $\begin{array}{l}\text { Wosmi mieschock wohn, } \\
\text { dapossli ssomenoi }\end{array}$ & $\begin{array}{l}\text { букв., Возми мешок вон, да поссли со мной } \\
\text { ссоменой [Возьми мешок вон, да пошли со мной] } \\
\text { «Возьми вон» употреблено в значении «вынеси» }\end{array}$ \\
\hline Cudi etoi dorógua poidiot? & $\begin{array}{l}\text { букв., Куды этой дорога пойдёт? [Куда эта дорога } \\
\text { идёт?] }\end{array}$ \\
\hline Do torssjoeck & $\begin{array}{l}\text { букв., До торжок [До Торжок, т.е. до Торжка (?)] } \\
\text { И.-А. Бранд переводит, как «на город» }\end{array}$ \\
\hline
\end{tabular}


Ot goroda

Mattigg jobo, vel Tycho pojé ssjai

Pojé ssjai sskoro

Mnógchole myle mjégchale ssousotne?

Mnogchole würst mjégchale is derevna?

Dersschémene loschsjet

Dersschémene ssapónie

Peauschallu

Büdetlie fskoreau sswietleau nadíeau?

От города

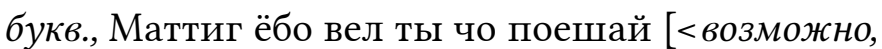
бранное выражение>, ты что поезжай]

букв., Поешай сскоро [Поезжай скоро]

букв., Многоле миле миегхале ссосотне? [Много ли миль мы ехали со сотни, возможно, «за сёдне», т.e. за сегодня]

Здесь возможно смешение с топонимом, например, Осотня - река на Смоленщине и деревня на Полотчине

букв., Многоле вюрст миегхале из деревна? [Много ли вёрст мы ехали из деревни?]

букв., Дерше мене лошадь [Держи мне лошадь] букв., Дерше мене сапоние [Держи мне супонь] И.-А. Бранд переводит, как «крепко держи мне стремя»

букв., Пошалу [Пожалуйста - так и в переводе И.-А. Бранда]

букв., Будет ли вскоре светло надо [Будет ли вскоре светло, надеюсь? (?)]

Таблица 4. | Table 4.

Большой массив выражений призван облегчить общение с русской прислугой, владельцами корчмы или постоялого двора по поводу обслуживания в комнате и приготовления пищи:

\begin{tabular}{ll}
\hline У автора: & Буквальное прочтение, перевод, пояснения: \\
\hline Postaéve phpeetch & букв., Поставе фпетч [Поставь в печь] \\
Wósme eaugón & букв., Возме огон исспетч [Возьми огонь из печи] \\
issphpéetch & \\
Teaupimene phpeetch & букв., Топи мене фпетч [Топи мне печь] \\
Polló schimene ssolóma & букв., Поло шимене ссолома ссмишок [Положи \\
ssmischjock & мене солома с мешок] \\
Kien zypka wohn & букв., Кин зипка вон [Кинь, т.е. выкинь зыбку вон] \\
Wipasche won peaul & букв., Випаше вон пол [Выпаши вон пол (?)] \\
Ssidi & букв., Ссиди [Сиди] \\
Ssidié tebié nakoigne & букв., Сиди тебе на когне [Сядь на коня (?)]
\end{tabular}


Poostave swetietz ssuda

Nysschnie málitz

Polloschy schapka nagóllova

Daime laesku natzem ssedsjítz

Proëtz malitz

Poddi wohn

Poddi wohn, tiotsschies noch pagchnes

Otworri dwerr

Ssakroy dwerr

Sskoroi jelay

Davai poietti

Daimene ssoloma

Daimene sswescha

Ssoloma, eta Ssoloma

pagchnet

Ssjena

Ssasjémene lucinu

Ssnimay sschwietz

Davaymene ináa lucina

Ssagasse lucinu букв., Поставе светитц ссуда [Поставь светец сюда]

букв., Нишни ма́литц [Нишкни ма́лец, m.e. помолчи, малещ]

букв., Полоши шапка наголова [Положи, т.e. надень, шапку на голову]

букв., Дайме ласку на тцем седить [Дай мне, ласку, на чем сидеть]

букв., Проетц малитц [Проедь, малец, т.е. дай дорогу]

букв., Поди вон

букв., Подди вон, ти от чеснох пагхнес [Поди вон, ты от чеснока пахнешь, т.е. чесноком пахнешь или от чеснока <дурно> пахнешь]

букв., Отворри дверр [Отвори дверь]

букв., Ссакрой дверр [Закрой дверь]

букв., Сскорой желай [Скорей желай (?) делай (?)]

И.-А. Бранд переводит это как «поторопись»

букв., Давай поети [Давай поесть или давай

взять/поять или давай поедем]

букв., Дай мене ссолома [Дай мне соломы]

букв., Дай мене ссвеша ссолома эта ссолома пахнет

[Дай мне свежую солому, эта солома <дурно>

пахнет]

букв., Ссена [Сено]

букв., Зажже мене луцину [Зажги мне лучину]

букв., Сснимай сшветц [Снимай свет (?) светец (?)

свечу (?)]

букв., Давай мене инаа луцина [Дай мне иную, т.e. другую, лучину]

букв., Ссагассе луцину [Загаси лучину]

Таблица 5. | Table 5.

Всего лишь несколько фраз относятся к торговле, что отличает словарь И.-А. Бранда от торговых словарей-разговорников: 


\begin{tabular}{ll}
\hline У автора: & Буквальное прочтение, перевод, пояснения: \\
\hline Stóte gchotsjes potsché & букв., Стоте гхочес почему тот тавар? [Что ты \\
mutot tawar? & хочешь, почем тот товар?] \\
Tak dóroga & букв., Так до́рога [Так дорого] \\
\hline
\end{tabular}

Таблица 6. | Table 6.

Ряд выражений характеризует возможность попадания в конфиликтые ситуации:

\begin{tabular}{ll}
\hline У автора: & Буквальное прочтение, перевод, пояснения: \\
\hline Predymene jesschódin & букв., Преди мене йесшодин након! [Приди ко \\
nakon! & мне ещё раз на кон!] \\
& И.-А. Бранд переводит это, как «давай ещё раз» \\
& букв., Якхочу теби пять орегхи дам [Я хочу тебе \\
Jacchotssjú tebié piath & <о>пять <на> орехи дать] \\
orégchie dam & В переводе И.-А. Бранда - дать пощечину \\
& букв., Давай емо пять орегхи [Дай ему <о>пять \\
Daváy jemó piath orégchie & $<$ оа> орехи] \\
& букв., Блединсин [Б \\
Blédinssin & букв., Шьорт [Чёрт] \\
Schjortj &
\end{tabular}

Таблица 7. | Table 7.

Структура и состав разговорника И.-А. Бранда имеет некоторые аналоги в других сочинениях своего жанра. Например, русская азбука и раздел «Число» существуют почти во всех иностранных словарях. Параллель набору приветственно-ответных фраз можно найти в разделе «Речи двух добрых друзей» немецко-русского словаря-разговорника Генриха Невенбурга 1629 г. Как отмечает Н. Г. Савич, приведенные в диалоге фразы выдержаны в подчеркнуто дружественном, сердечном тоне (Савич, 1978, с. 275). Вместе с тем разговорник И.-А. Бранда по своему составу - это пособие именно для путешественника. В отличие от него словари Т. Шрове, Т. Фенне и Г. Невенбурга содержат лексику, связанную с ведением хозяйства и необходимую людям, подолгу проживающим в чужих городах.

\section{ВЫВОДЫ}

Словарь-разговорник И.-А. Бранда является ценным источником по истории дорожного быта своего времени. Состав словаря-разговор- 
ника позволяет воссоздать бытовые реалии жизни Бранденбургского посольства в дороге. Можно предположить, что в костюм обычного участника входили рубаха, кафтан на пуговицах, штаны, чулки и башмаки, ремень с пряжкой, вязаные перчатки, рукавицы и шляпа. Какая-то теплая одежда была подбита упомянутым мехом куницы. Также у путешественника с собой были шапочка для сна, частью костюма были карманы, шейные и носовые платки.

На стоянках и во время пути возникала возможность для общения с местными людьми, в том числе и для обмена лексикой. Этот обмен иногда был затруднен, а иногда сопровождался подшучиванием над приезжими, возможно, передразниванием иностранной речи (см. комплекс слов, дополненных фрагментом «стер»: слугастери, здестери).

Вопросы покупки продовольствия, судя по набору фраз в разговорнике, Иоганна Бранда волновали мало. Вероятно, этим занимались специальные люди, и составитель не был свидетелем их общения.

Бытовое обеспечение посольства выглядит солидно, если, конечно, лексика словаря не отображает запросы его составителя. Эти запросы могли далеко не всегда удовлетворяться. Мясные продукты в словаре представляют баран, гусь, курица, индейка, курица. Жаркое на вертеле, по данным И.-А. Бранда, русские называют словом «шялык», весьма напоминающим «шашлык». Также упоминается рыба. В отличие от словаря-разговорника Тонни Фенне, где перечисление рыб и сопутствующей лексики занимает три страницы (Hendriks \& Schaeken, 2008, ss. 71-73), упоминание рыбы у Иоганна Бранда единично. Из овощей удостоилась попадания в словарь лишь капуста и, по ошибке, красная свекла. Учитывая, что путешествие проходило уже в зимние месяцы, присутствие в словаре запроса о «свежей капусте» выглядит со стороны участников посольства как прихоть. Впрочем, речь могла идти о несвежем блюде либо о неприятии кислой или квашеной капусты.

Названы как хлеб, так и каравай, упоминаются мука, яйца, масло, а также соль, перец и изюм. Из напитков словарь перечисляет воду, молоко, вино и горилку, а также пиво. Отдельно названа «скляница», в которой мог находиться какой-то крепкий напиток.

Столовые приборы, которые называет словарь И.-А. Бранда, включают нож и вилку. О названиях ложек автору удалось узнать лишь то, что существует деревянный половник и ложка для снятия пены. Никакой посуды, в которой готовили, И.-А. Бранд не упоминает.

Для трапезы накрывали стол. Стулья или лавки не упоминаются, но в словаре есть вежливая фраза «дай мне, ласку, на чем седить». 
Грелись представители посольства у печей, о чем говорят упоминание требования истопить печь и обозначения всего, что с нею связано: дрова, уголь, огонь.

Свет в помещениях давала лучина, закрепленная в светец, либо свечи в подсвечниках. И.-А. Бранду, как можно видеть из его текста, для общения потребовались фразы о замене лучины - ведь ему был необходим свет, чтобы вести свои заметки.

Из средств передвижения И.-А. Бранд называет карету, рыдван, сани и телегу. Учитывая время года, колесные повозки и колеса автор мог, скорее всего, видеть не на ходу, а на поветях станций и постоялых дворов. Однако один раз в словаре присутствует перевод для требования принести багаж на «те ега» (предположительно, «телега»). О верховом конном передвижении свидетельствуют слова «супонь» (русское) и «стремя» (немецкое).

В услужении у членов посольства была русская прислуга. И.-А. Бранд дважды называет слово «малиц» (вероятно, «малец»), один раз «слуга» (может быть, вежливый оборот, не относящийся к прислуге). Возможно, именно к ним обращены требования убрать в комнате, перенести вещи, зажечь или погасить огонь, и другие императивы.

Также упоминаются и ямщики, которые везли посольство от места до места. Судя по расположению фраз в разговорнике, в обязанности прислуги, а иногда и ямщиков входила погрузка багажа (упоминаются «коропки» и «чемодан») и добыча свежего сена или соломы. Сено в записках путешественников, в целом, фигурирует как стратегический ресурс - на нем спали, его набивали в тюфяки, его укладывали в повозки (Tende, 1686, pp. 326-330). Особую заботу составляло попечение о свежести сена. Эта традиция поддерживается и словарем Иоганна Бранда: два раза упоминается сено, пять раз солома, и еще один раз - мешок, видимо, тоже с соломой.

Разговоры во время переездов, судя по тексту И.-А. Бранда, касались направлений дороги, расстояний и времени дня. Лексика, касающаяся погоды или качества дороги, в словаре отсутствует. Выражение «приди мене ещё один на кон» может косвенно свидетельствовать о практике азартных игр или о драках. Автор счел возможным включить в разговорник и бранные выражения, а также фразы с угрозами. Вероятно, конфликтные ситуации на протяжении поездки посольства также присутствовали. 


\section{БЛАГОДАРНОСТИ}

Исследование выполнено при финансовой поддержке РФФИ и БРФФИ в рамках научного проекта № 20-59-00015 «Антропология дороги: коммуникации русско-белорусского пограничья в XIV-XVIII BB.».

The reported study was funded by RFBR and BRFBR, project number 2059-00015 "Anthropology of the road: communications of the RussianBelarusian borderland in XIV-XVIII centuries”.

\section{Список литературы}

Brand, J. A. (1702). Reysen, durch die Marck Brandenburg, Preussen, Churland, Liefland, Plesscovien, Gross-Naugardien, Tweerien und Moscovien: In welchen vieles nachdencklich wegen gemeldter Länder, ... Anbey Eine Seltsame und sehr Anmerckliche Beschreibung von Siberien [Reysen, durch die Marck Brandenburg, Preussen, Churland, Liefland, Plesscovien, Gross-Naugardien, Tweerien und Moscovien: In denen viel nachdencklich wegen gemeldter Länder, ... Anbey A Strange and Very Remarkable Description of Siberia]. Wesel: J. von Wesel. (In German).

Günther, E. (1965). Russische Wörter und Redewendungen in einer Reisebeschreibung von 1673. Wissenschaftliche Zeitschrift der Humboldt-Universität zu Berlin, 14(5), 757-765.

Hendriks, P., \& Schaeken, J. (Eds.). (2008). Tönnie`s Fenne’s Low German Manual of Spoken Russian, Pskov 1607 (An electronic text). Leiden: Opl. Slavistiek. Retrieved from http://www.schaeken.nl/lu/research/online/editions/fenne11.pdf

Hirsch, F. (1906). Urkunden und Aktenstücke zur Geschichte des Kurfürsten Friedrich Wilhelm von Brandenburg. Band 19: Politische Verhandlungen [Documents and records on the history of Elector Frederick William of Brandenburg. Volume 19: Political negotiations]. Berlin: G. Reimer. (In Germany).

La Mottraye, A. (1732). Voyages, en anglois et en françois, d'A. de La Motraye en diverses provinces et places de la Prusse ducale et royale, de la Russie, de la Pologne, etc. [Texte imprimé], contenant un traité de divers ordres de chevalerie, un grand nombre de particularités curieuses touchant le tumulte de Thorn, la diette de Grodno, la vie de... Pierre I, celles de l'impératrice Catherine, du général Le Fort et du prince Menzikoff, avec des remarques géographiques, topographiques, historiques et politiques sur ces provinces et autres païs par lesquels l'auteur a passé. La Haye: A. Moetjens [Travels, in English and French, of A. de La Motraye in various provinces and places of ducal and royal Prussia, Russia, Poland, etc. [Printed text], containing a treatise on various orders of chivalry, a great number of curious particulars concerning the tumult of Thorn, the diette of Grodno, the life of the... [Printed text], containing a treatise on various orders of chivalry, a great number of curious particulars concerning the tumult of Thorn, the dietta of Grodno, the life of... Peter I, the Empress Catherine, General Le Fort and Prince Menzikoff, with geographical, topographical, historical and political remarks on these 
provinces and other countries through which the author passed]. La Haye: A. Moetjens. (In French).

Tende, G. (1686). Relation historique de la Pologne contenant le pouvoir de ses rois, leur élection, \& leur couronnement, les privileges de la noblesse, la religion, la justice, les moeurs \& les inclinations des Polonois; avec plusieurs actions remarquables. Par le Sieur de Hauteville [Relation historique de la Pologne contenant le pouvoir de ses rois, leur élection, \& leur couronnement, les privileges de la noblesse, la religion, la justice, les mours \& les inclinations des Polonois; avec plusieurs actions remarquables. By the Sieur de Hauteville]. Paris: J. Villery. (In French).

Алексеев, М. П. (1936). Сибирь в известиях западно-европейских путешественников и писателей: Введение, тексты и комментарии. Иркутск: КРАЙГИЗ.

Бантыш-Каменский, Н. Н. (1902). Обзор внешних сношений России (по 1800 г.). Москва: Комиссия печатания государственных грамот и договоров при Московском главном архиве Министерства Иностранных дел.

Болек, А. (2003). Псковские разговорники-словари в работах краковских ученых. В Псков в российской и европейской истории: Международная научная конференция (Т. 2, сс. 213-218). Москва: МГУП.

Витсен, Н. (1996). Путешествие в Московию, 1664-1665: Дневник (В. Г. Трисман, Пер.). Санкт-Петербург: Simposium.

Кирпичников, А. Н. (1994). Сообщения немецкого путешественника Самуэля Кихеля о Пскове XVI в. Публикация источника и исследования. Часть I (публикация источника). Вестник Санкт-Петербургского университета. Серия 2. История языкознание, литературоведение, (2), 3-8.

Кирпичников, А. Н. (1995). Сообщение Иоганна Вундерера о Пскове и России 1590 г. Исследование и публикация источника. В Славяно-русские древности. Выпуск 3. Проблемы истории Северо-Запада Руси (сс. 167-217). Санкт-Петербург: Издательство СПбГУ.

Коваленко, Г. М. (Ред.). (2002). Великий Новгород в иностранных сочинениях XV - нач. $X X$ века. Великий Новгород: НовГУ им. Ярослава Мудрого.

Костючук, Л. Я. (2003). Псков XVI-XVII веков глазами иностранцев. (Понимание языковой картины мира через впечатления от незнакомого). Псков. Научнопрактический, историко-краеведческий журнал, (19), 41-47.

Костючук, Л. Я. (2020). Уникальные источники о торговых отношениях и быте псковичей XVI-XVII вв. Метаморфозы истории, (15), 120-134.

Левинсон, Н. Р. (1945). Записки Айрманна о Прибалтике и Московии 1666-1670 гг. Исторические записки, (17), 265-307.

Левичкин, А. Н. (2017). Отрывок русско-голландского словаря XVII века из Пскова. В А. С. Герд \& Е. В. Пурицкая (Ред.), Севернорусские говоры. Выпуск 16 (сс. 196235). Санкт-Петербург: Издательство «Нестор-История».

Мжельская, О. С. (1984). Лексика псковского рынка начала XVII в. В А. С. Герд \& В. В. Колесов (Ред.), Севернорусские говоры. Межвузовский сборник. Выпуск 4 (сс. 8496). Ленинград: Издательство ЛГУ. 
Мжельская, О. С. (1988). Лексика судоходства в «Разговорнике» Т. Фенне. В О. А. Черепанова (Ред.), Русская историческая лексикология и лексикография. Выпуск 4 (сс. 127-142). Ленинград: Издательство ЛГУ.

Мжельская, О. С. (2003). Лексика обиходно-разговорного языка Московской Руси XVI-XVII вв.: По даннымм иностранных руководств для изучения русского языка. СанктПетербург: Издательство СПбГУ.

Мжельская, О. С. (2010). Из названий товаров на Псковском рынке (XVI-XVII вв.). В О. А. Черепанова (Ред.), Историческая лексикология и лексикография: Межвузовский сборник. Выпуск 8 (сс. 99-117). Санкт-Петербург: Филологический факультет СПбГУ.

Мжельская О. С., \& Костючук Л. Я. (2003). Русско-иноязычные разговорники XVIXVII вв. Как источники сведений о жизни древнего Пскова и его обитателей (псковский торг). В Псков в российской и европейской истории: Международная научная конференция (Т. 2, сс. 207-212). Москва: МГУП.

Поссевино, А. (1983). Исторические сочинения о России XVI в. («Московия», «Ливония» и др.) (Л. Н. Годовикова, Пер.). Москва: Издательство МГУ.

Пушкарев, Л. Н. (2004). Освоение русского языка иностранцами в конце XVI-XVII вв. Bопросы истории, (6), 121-128.

Савич, Н. Г. (1978). Из истории русско-немецких культурных связей в XVII в. (Немецко-русский словарь-разговорник Г. Невенбурга 1629 г.). Исторические записки, (102), 246-286.

Селарт, А. (2014). Тайна купцов, забота дипломатов: Русский язык в средневековой Ливонии. В Л. Н. Киселева \& Т. Н. Степанищева (Ред.), Лотмановский сборник. Выпуск 4. Москва: ОГИ.

Стрейс, Я. Я. (1935). Три путешествия (А. Морозова, Ред.; Э. Бородина, Пер.). Москва: ОГИЗ-Соцэкгиз.

Форстен, Г. В. (1900). К внешней политике великого курфюрста Фридриха Вильгельма Бранденбургского. Журнал министерства народного просвещения, (330), 22-58, 304-336.

Хорошкевич, А. Л. (1999). Из истории создания немецко-русских словарей-разговорников «Томаса Шрове» и «Тонниса Фенне». В Древности Пскова. Археология. История. Архитектура. К юбилею Инги Константиновны Лабутиной (сс. 218230). Псков: Псковская областная типография.

\section{References}

Alekseev, M. P. (1936). Siberia in the notes of West European travelers and writers: introduction, texts and comments. Irkutsk: KRAYGIZ. (In Russian).

Bantysh-Kamensky, N. N. (1902). Review of external relations of Russia (up to 1800). Part 4: (Prussia, France, Sweden). Moscow: Commission for state certificates and contracts printing at the Moscow Main Archive of the Ministry of Foreign Affairs. (In Russian). 


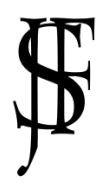

Журнал Фронтирных Исследований. 2021. No 3 | ISSN: 2500-0225

Российский фронтир | Doi: https://doi.org/10.46539/jfs.v6i3.296

Bolek, A. (2003). Pskov phrasebooks-dictionaries in the works of Krakow scientists. In Pskov in Russian and European history: International scientific conference (Vol. 2, pp. 213218). Moscow: MGUP. (In Russian).

Brand, J. A. (1702). Reysen, durch die Marck Brandenburg, Preussen, Churland, Liefland, Plesscovien, Gross-Naugardien, Tweerien und Moscovien: In welchen vieles nachdencklich wegen gemeldter Länder, ... Anbey Eine Seltsame und sehr Anmerckliche Beschreibung von Siberien [Reysen, durch die Marck Brandenburg, Preussen, Churland, Liefland, Plesscovien, Gross-Naugardien, Tweerien und Moscovien: In denen viel nachdencklich wegen gemeldter Länder, ... Anbey A Strange and Very Remarkable Description of Siberia]. Wesel: J. von Wesel. (In German).

Forsten, G. V. (1900). To the foreign policy of the great Kurfust Friedrich Wilhelm of Brandenburg. Journal of the Ministry of Public Education, (330), 22-58, 304-336. (In Russian).

Günther, E. (1965). Russische Wörter und Redewendungen in einer Reisebeschreibung von 1673. Wissenschaftliche Zeitschrift der Humboldt-Universität zu Berlin, 14(5), 757-765.

Hendriks, P., \& Schaeken, J. (Eds.). (2008). Tönnie`s Fenne’s Low German Manual of Spoken Russian, Pskov 1607 (An electronic text). Leiden: Opl. Slavistiek. Retrieved from http://www.schaeken.nl/lu/research/online/editions/fenne11.pdf

Hirsch, F. (1906). Urkunden und Aktenstücke zur Geschichte des Kurfürsten Friedrich Wilhelm von Brandenburg. Band 19: Politische Verhandlungen [Documents and records on the history of Elector Frederick William of Brandenburg. Volume 19: Political negotiations]. Berlin: G. Reimer. (In Germany).

Khoroshkevich, A. L. (1999). From the history of German-Russian dictionaries-phrasebooks "Thomas Schrove" and "Tonnis Fenne" creation. In Antiquities of Pskov. Archaeology. History. Architecture. To Inga Konstantinovna Labutina anniversary (pp. 218-230). Pskov: Pskov Regional Printing House. (In Russian).

Kirpichnikov, A. N. (1994). Notes of the German traveler Samuel Kihel about Pskov of the 16th century. Source and research publication. Part I (source publication). Bulletin of St. Petersburg University. Series 2. History, Linguistics, Literary criticism, (2), 3-8. (In Russian).

Kirpichnikov, A. N. (1995). Report of Johann Wunderer about Pskov and Russia in 1590. Research and publication of the source. In Slavic-Russian antiquities. Issue 3. Problems of the history of North-West Russia (pp. 167-217). St. Petersburg: St. Petersburg University Press. (In Russian).

Kostyuchuk, L. Ya. (2003). Pskov of the XVI-XVII cc. through the eyes of foreigners (understanding the linguistic picture of the world through the impressions of the stranger). Pskov. Scientific and practical, historical and local history journal, (19), 41-47. (In Russian).

Kostyuchuk, L. Ya. (2020). Unique sources on trade relations and life of the pskovites of the XVI-XVII. Metamorphoses of history, (15), 120-134. (In Russian).

Kovalenko, G. M. (Ed.). (2002). eliky Novgorod in foreign works of the XV-early XX century. Veliky Novgorod: NovSU named after Yaroslav the Wise. (In Russian). 
La Mottraye, A. (1732). Voyages, en anglois et en françois, d'A. de La Motraye en diverses provinces et places de la Prusse ducale et royale, de la Russie, de la Pologne, etc. [Texte imprimé], contenant un traité de divers ordres de chevalerie, un grand nombre de particularités curieuses touchant le tumulte de Thorn, la diette de Grodno, la vie de... Pierre I, celles de l'impératrice Catherine, du général Le Fort et du prince Menzikoff, avec des remarques géographiques, topographiques, historiques et politiques sur ces provinces et autres païs par lesquels l'auteur a passé. La Haye: A. Moetjens [Travels, in English and French, of A. de La Motraye in various provinces and places of ducal and royal Prussia, Russia, Poland, etc. [Printed text], containing a treatise on various orders of chivalry, a great number of curious particulars concerning the tumult of Thorn, the diette of Grodno, the life of the... [Printed text], containing a treatise on various orders of chivalry, a great number of curious particulars concerning the tumult of Thorn, the dietta of Grodno, the life of... Peter I, the Empress Catherine, General Le Fort and Prince Menzikoff, with geographical, topographical, historical and political remarks on these provinces and other countries through which the author passed]. La Haye: A. Moetjens. (In French).

Levichkin, A. N. (2017). An excerpt from the Russian-Dutch dictionary of the XVII century from Pskov. In A. S. Gerd \& E. V. Puritskaya (Eds.), Northern Russian dialects. Issue 16 (pp. 196-235). St. Petersburg: Publishing house «Nestor-Istoriya». (In Russian).

Levinson, N. R. (1945). Ayrmann's notes on the Baltic and Muscovy 1666-1670. Historical notes, (17), 265-307. (In Russian).

Mzhelskaya, O. S. (1984). Vocabulary of the Pskov market at the beginning of the XVII century. In A. S. Gerd \& V. V. Kolesov (Eds.), North Russian dialects. Interuniversity collection. Issue 4 (pp. 84-96). Leningrad: Leningrad State University Press. (In Russian).

Mzhelskaya, O. S. (1988). Shipping vocabulary in the Phrasebook by T. Fenne. In O. A. Cherepanova (Ed.), Russian historical lexicology and lexicography. Issue 4 (pp. 127142). Leningrad: Leningrad State University Press. (In Russian).

Mzhelskaya, O. S. (2003). Vocabulary of everyday-spoken language of Muscovite Russia of the XVI-XVII: According to foreign guidelines for Russian language study. St. Petersburg: St. Petersburg University Press. (In Russian).

Mzhelskaya, O. S. (2010). From the names of goods in the Pskov market (XVI-XVII). In O. A. Cherepanova (Ed.), Historical lexicology and lexicography: interuniversity collection. Issue 8 (pp. 99-117). St. Petersburg: Faculty of Philology, St. Petersburg State University. (In Russian).

Mzhelskaya, O. S., \& Kostyuchuk, L. Ya. (2003). Russian-foreign language phrasebooks of the XVI-XVII cc. as sources of information about the life of ancient Pskov and its inhabitants (Pskov market). In Pskov in Russian and European history: International scientific conference (Vol. 2, pp. 207-212). Moscow: MGUP. (In Russian).

Possevino, A. (1983). Historical writings about Russia in the XVI c. ("Muscovy”, "Livonia”, etc.) (L. N. Godovikova, Trans.). Moscow: Moscow University Press. (In Russian).

Pushkarev, L. N. (2004). Mastering Russian by foreigners at the end of the XVI-XVII. Issues of History, (6), 121-128. (In Russian). 
Savich, N. G. (1978). To the history of Russian-German cultural relations in the 17th century. (German-Russian dictionary-phrasebook by G. Nevenburg 1629). Historical notes, (102), 246-286. (In Russian).

Selart, A. (2014). Mystery of merchants, care of diplomats: the Russian language in Medieval Livonia. In L. N. Kiseleva \& T. N. Stepanishcheva (Eds.), Lotmanovsky collection. Issue 4. Moscow: OGI. (In Russian).

Streis, J. J. (1935). Three journeys (A. Morozova, Ed.; E. Borodina, Trans.). Moscow: OGIZSotsekgiz. (In Russian).

Tende, G. (1686). Relation historique de la Pologne contenant le pouvoir de ses rois, leur élection, \& leur couronnement, les privileges de la noblesse, la religion, la justice, les mours \& les inclinations des Polonois; avec plusieurs actions remarquables. Par le Sieur de Hauteville [Relation historique de la Pologne contenant le pouvoir de ses rois, leur élection, \& leur couronnement, les privileges de la noblesse, la religion, la justice, les mours \& les inclinations des Polonois; avec plusieurs actions remarquables. By the Sieur de Hauteville]. Paris: J. Villery. (In French).

Witsen, N. (1996). Journey to Muscovy, 1664-1665: Diary (V. G. Trisman, Trans.). St. Petersburg: Simposium. (In Russian). 